\title{
PRKCB wt Allele
}

National Cancer Institute

\section{Source}

National Cancer Institute. PRKCB wt Allele. NCI Thesaurus. Code C51272.

Human PRKCB1 wild-type allele is located in the vicinity of $16 p 11.2$ and is approximately $384 \mathrm{~kb}$ in length. This allele, which encodes protein kinase $\mathrm{C}$ beta type protein, plays a role in the phosphorylation of many protein substrates in response to activation by calcium or the second messenger diacylglycerol. Certain allelic variants of the PRKCB1 gene are associated with susceptibility to diabetic nephropathy in individuals with either type I or type II diabetes mellitus. 